Article

\title{
Outer Membrane Protein of Gut Commensal Microorganism Induces Autoantibody Production and Extra-Intestinal Gland Inflammation in Mice
}

\author{
Naoko Yanagisawa *, Hidehiro Ueshiba, Yoshihiro Abe, Hidehito Kato, Tomoaki Higuchi and \\ Junji Yagi \\ Microbiology and Immunology, Tokyo Women's Medical University, Tokyo 162-8666, Japan; \\ ueshiba.hidehiro@twmu.ac.jp (H.U.); lagwagon0423@yahoo.co.jp (Y.A.); kato.hidehito@twmu.ac.jp (H.K.); \\ higuchi.tomoaki@twmu.ac.jp (T.H.); yagi.junji@twmu.ac.jp (J.Y.) \\ * Correspondence: yanagisawa.naoko@twmu.ac.jp; Tel.: +81-3-3353-8111
}

Received: 30 August 2018; Accepted: 15 October 2018; Published: 19 October 2018

check for updates

\begin{abstract}
Gut commensal microorganisms have been linked with chronic inflammation at the extra-intestinal niche of the body. The object of the study was to investigate on the chronic effects of a gut commensal Escherichia coli on extra-intestinal glands. The presence of autoimmune response was diagnosed by autoantibody levels and histological methods. Repeated injection of E. coli induced mononuclear cell inflammation in the Harderian and submandibular salivary glands of female C57BL/6 mice. Inflammation was reproduced by adoptive transfer of splenocytes to immune-deficient Rag2 knockout mice and $\mathrm{CD}^{+} \mathrm{T}$ cells to mature $\mathrm{T}$ cell-deficient TCR $\beta$-TCR $\delta$ knockout mice. MALDI TOF mass spectrometry of the protein to which sera of E. coli-treated mice reacted was determined as the outer membrane protein A (OmpA) of E. coli. Multiple genera of the Enterobacteriaceae possessed OmpA with high amino-acid sequence similarities. Repeated injection of recombinant OmpA reproduced mononuclear cell inflammation of the Harderian and salivary glands in mice and elevation of autoantibodies against Sjögren's-syndrome-related antigens SSA/Ro and SSB/La. The results indicated the possibility of chronic stimuli from commensal bacteria-originated components as a pathogenic factor to elicit extra-intestinal autoimmunity.
\end{abstract}

Keywords: commensal bacteria; autoantibody; Harderian gland; salivary gland

\section{Introduction}

The structure of the human gut microbiota is established early in life, and thereafter maintains a symbiotic relationship with their host in an anaerobic environment for decades [1,2]. Escherichia coli, a facultative anaerobe from the Proteobacteria phylum and a key member of the Enterobacteriaceae family [3], colonize the intestine of human infants within hours of birth [4], by their ability to respire oxygen in the intestine of newborns [5,6]. Although early colonization of E. coli is indispensable for the development of oral tolerance [7], Enterobacteriaceae constitute only a small fraction of less than $1 \%$ of the gut microbiota in healthy adults [8] due to restricted carbohydrate sources that they need for growth, for which they compete with the obligate anaerobe counterparts [9]. Nitrate can be used for anaerobic respiration in Enterobacteriaceae, thus conferring growth advantage to E. coli by a high protein diet lifestyle [10-13]. Dysbiosis of increased facultative anaerobes exceeds commensal tolerance and stimulates innate immune activation beyond the intestinal niche [14], such as atherosclerosis [14,15]. Several of the bacterial components have been implicated in the development of autoimmunity, including the microbial-von Willebrand factor type A domain protein (vWFA) [16] and the flagellin FliC [17] in sialoadenitis of Sjögren's syndrome (SS), and the outer membrane protein OmpC in the synovial membrane of rheumatoid arthritis [18]. 
OmpA is one of the most abundant proteins expressed at high levels up to 100,000 copies per cell on the outer membrane of Enterobacteriaceae [19] to maintain cell integrity under osmotic stress [20]. The structure of OmpA from E. coli is composed of 325 amino acids consisting of $\mathrm{N}$-terminal 171 residues, which adopt $\beta$-barrel domain composed of eight membrane-spanning $\beta$-strands [21]. An alternative temperature dependent conformation consists of 16-stranded $\beta$-barrel involving an additional eight $\beta$-strands from the C-terminal domain, which unless they reside in the periplasm, corresponding to a large pore [22]. Given its copy number and location, OmpA also interacts with and modulates host immunity by inactivating the complement cascade [20,23], and evading leukocyte killing by suppression of reactive oxygen species [24]. Therefore, attention has been paid to OmpA as a multifunctional immune modulating enterobacterial protein [25].

The present study was objected to investigate the possibility of gut microorganism in the pathogenesis of extra-intestinal autoimmunity. The presence of autoimmunity in the present study was diagnosed in female C57BL/6 mice by autoantibody levels and histology of the head and neck glands, including the submandibular salivary gland and the retro-orbital Harderian gland, which possesses combined species-variable abilities in exocytotic lipid-rich secretion, melatonin and porphyrin synthesis [26], and retinoic acid biosynthesis as the source of molybdoflavoenzyme [27]. The findings of the present study indicate that chronic stimuli from the outer membrane protein of commensal E. coli may act to trigger inflammatory cell infiltration in the extra-intestinal glands and production of autoantibodies.

\section{Results}

\subsection{Effect on Extra-Intestinal Gland Inflammation by Systemic Treatment of Mice with Bacterial Components}

To examine whether chronic exposure of bacteria or bacterial cell wall components could induce autoimmunity in mice by systemic immunization, six weeks old mice were treated with E. coli, peptidoglycan (PGN), muramyl dipeptide (MDP), lipoteichoic acid (LTA), lipopolysaccharide (LPS) or phosphate buffered saline (PBS), by intraperitoneal injection once a week for a total of eight weeks. Harderian glands and salivary glands were histologically examined fifteen weeks after the final treatment. Harderian glands of E. coli-treated mice showed infiltration of inflammatory cells (Figure 1B,M), in comparison to no inflammation in those of mice treated with PBS alone (Figure 1A). The incidence of at least one foci of inflammation in the Harderian gland occurred in all seven mice of the E. coli-treated group (Figure 1O). Inflammation in the Harderian gland was not detected in mice receiving PGN, MDP, LTA or LPS (Figure 1C-F). Inflammatory cells were present in the salivary glands of E. coli-treated mice (Figure $1 \mathrm{H}, \mathrm{N}$ ). Incidence of at least one foci in the salivary gland occurred in three of a total of seven mice in the E. coli-treated group (Figure 1O). Inflammation in the salivary gland was not detected in mice treated with PGN, MDP, LTA, LPS, or PBS (Figure 1G,I-L). Quantification of the inflammatory foci showed that foci were scattered within one sample organ (Figure 1O).

\subsection{Cell-Mediated Immunity in Bacteria-Treated Mice}

E. coli induced accumulation of inflammatory cells in the Harderian glands (Figure 2A,I,L). No inflammatory cells were observed in mice treated with PBS alone (Figure 2E,L). Infiltrating cells in the Harderian glands of the E. coli-treated mice were in part CD3 positive cells detected by immunohistochemistry (Figure 2D), which were not detected in the PBS-treated mice. IgG1 positive cells were scattered within the stromal tissue of the Harderian glands of mice by E. coli treatment (Figure 2H). IgG1 cells were not observed in the Harderian glands of mice treated with PBS.

Adoptive transfer experiments were undertaken to elucidate the role of cell-mediated immune responses in mice induced by repeated E. coli injection. Adoptive transfer of bulk splenocytes to Rag2 KO mice from E. coli-treated donor mice developed accumulation of inflammatory cells in the Harderian glands (Figure 2B,J,L), compared to those from donor mice receiving PBS alone (Figure 2F,L). Similarly, Harderian glands of TCR $\beta$-TCR $\delta$ KO mice subsequent to adoptive transfer of spleen-derived 
$\mathrm{CD}^{+} \mathrm{T}$ cells from E. coli-treated donor mice showed infiltration of inflammatory cells (Figure $2 \mathrm{C}, \mathrm{K}, \mathrm{L}$ ), but not those from donor mice receiving PBS alone (Figure 2G).
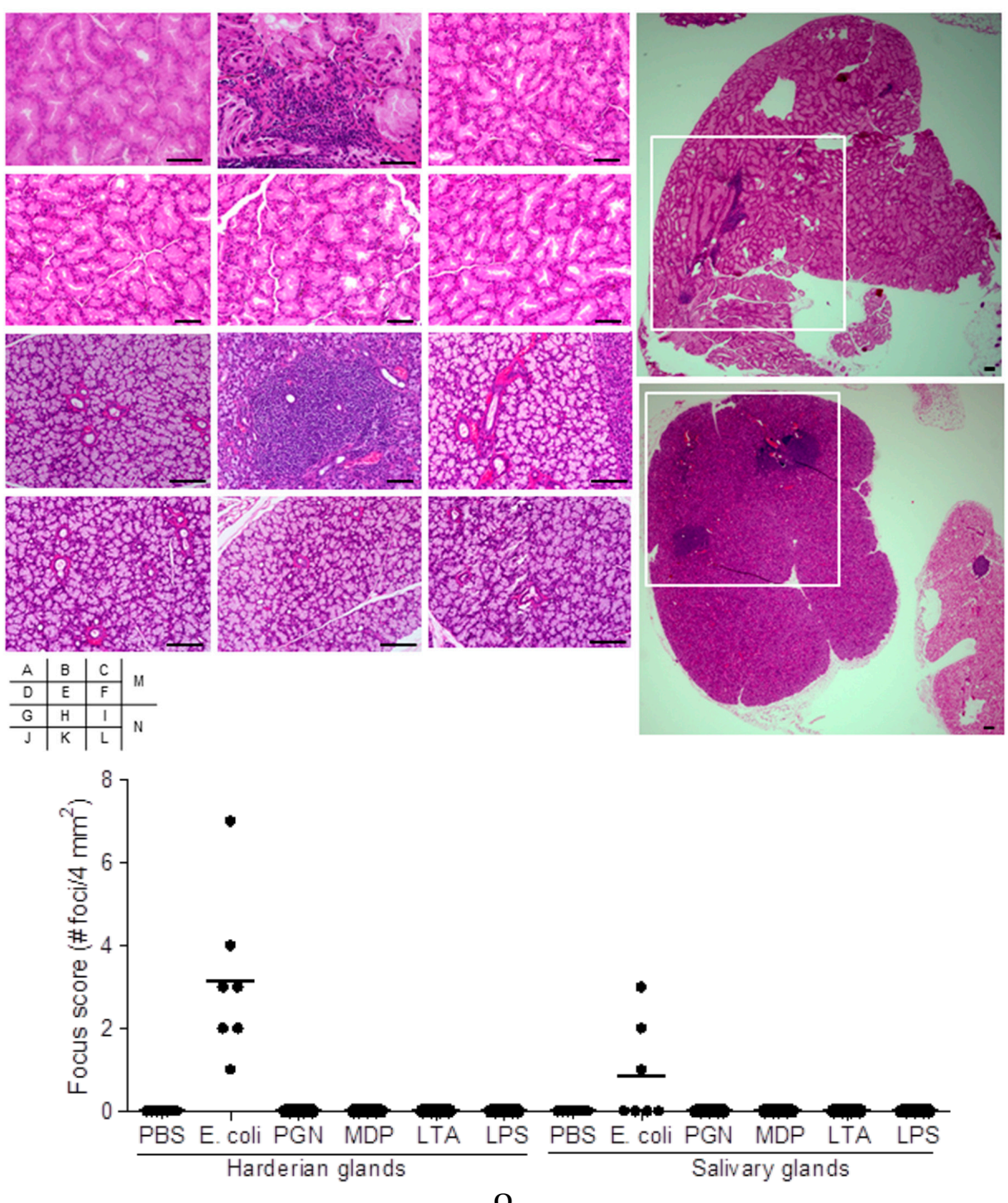

O

Figure 1. Histology of mice injected with bacteria or bacterial cell wall components. C57BL/ 6 female mice were repeatedly treated with $E$. coli $(\mathbf{B}, \mathbf{H}, \mathbf{M}, \mathbf{N}), \operatorname{PGN}(\mathbf{C}, \mathbf{I})$, MDP $(\mathbf{D}, \mathbf{J})$, LTA $(\mathbf{E}, \mathbf{K})$ or LPS (F,L), respectively, for eight weeks. Harderian glands $(\mathbf{B}-\mathbf{F}, \mathbf{M})$ and salivary glands $(\mathbf{H}-\mathbf{L}, \mathbf{N})$ fifteen weeks after the final inoculation of E. coli were visualized by hematoxylin and eosin (HE) staining and were compared to those of mice treated with PBS alone (A,G, respectively). A representative inflammatory focus in one mouse of seven mice per treatment group is presented (A-L). A representative area of $2 \mathrm{~mm} \times 2 \mathrm{~mm}$ is indicated as a white-lined square in a histologic section of the Harderian gland $(\mathbf{M})$ and the salivary gland $(\mathbf{N})$, respectively, visualized at low magnification $(4 \times)$. Scale bar, $100 \mu \mathrm{m}$. Quantification of inflammatory foci in Harderian and salivary glands. The number of inflammatory foci, each containing at least 50 mononuclear cells, was defined as \# foci (O). Data presented are individual values $(n=7)$ plotted with a bar indicating the group mean. Differences between the groups of measurements were analyzed by Kruskal-Wallis with post-test comparison. Focus scores of the Harderian glands in E. coli-treated group were significantly higher $(p<0.05)$ compared to all other measurement groups (O). PBS: phosphate buffered saline; PGN: peptidoglycan; MDP: muramyl dipeptide; LTA: lipoteichoic acid; LPS: lipopolysaccharide. 

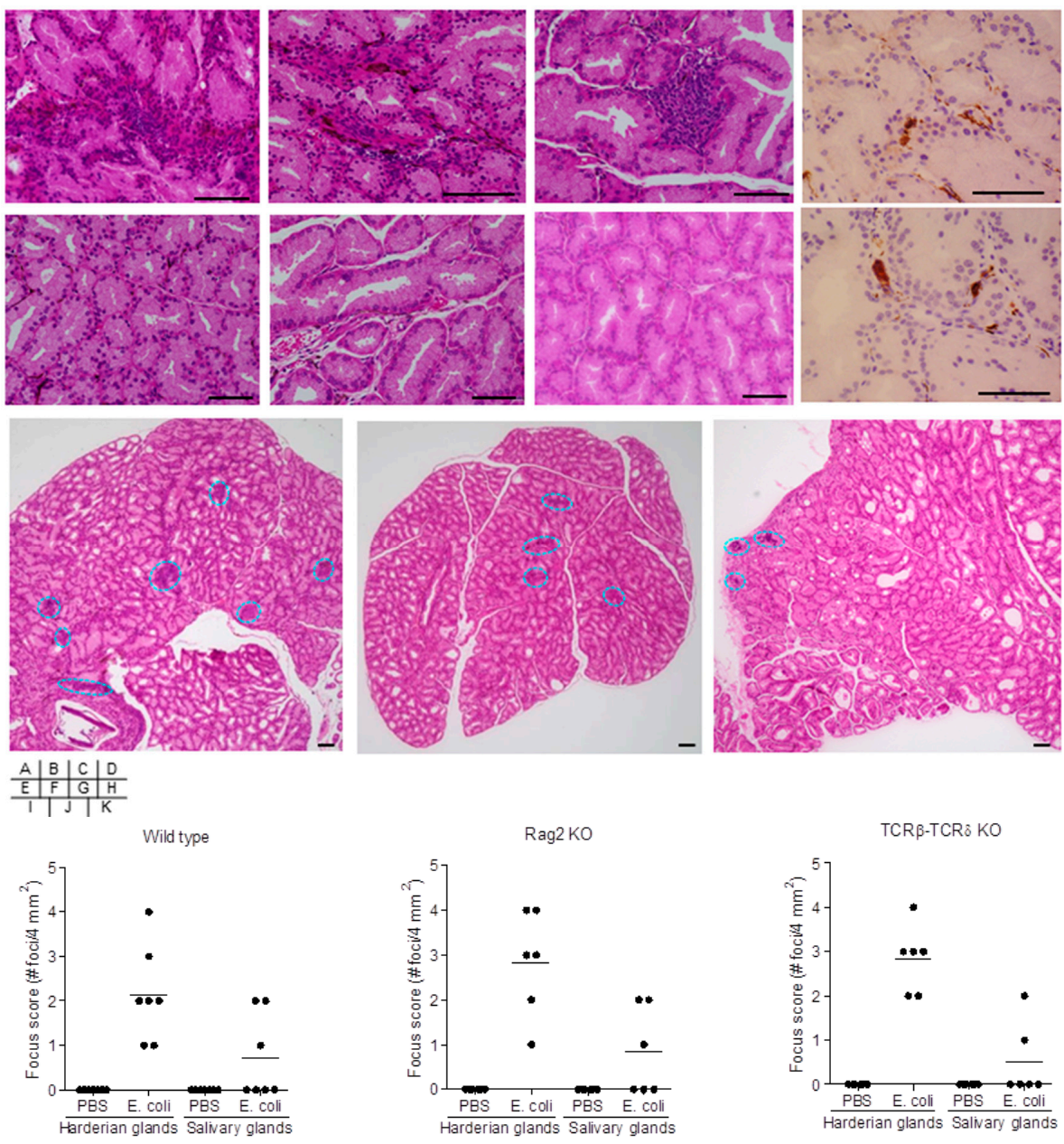

Figure 2. Histology of mice injected with E. coli. Harderian glands of E. coli-treated $(\mathbf{A}, \mathbf{D}, \mathbf{H}, \mathbf{I})$ and PBS-treated (E) C57BL/6 wild type mice were histologically examined fifteen weeks after the final injection. Harderian glands of Rag2 KO mice $(\mathbf{B}, \mathbf{F}, \mathbf{J})$ and TCR $\beta-T C R \delta$ KO mice $(\mathbf{C}, \mathbf{G}, \mathbf{K})$ were histologically examined one week after adoptive transfer of splenocytes $(\mathbf{B}, \mathbf{F}, \mathbf{J})$ or $\mathrm{CD}^{+} \mathrm{T}$ cells $(\mathbf{C}, \mathbf{G}, \mathbf{K})$ from E. coli-inoculated (B,C,J,K) or PBS-inoculated (F,G) C57BL/ 6 donor mice. Inflammatory infiltrates were examined by HE-staining (A-C,E-G,I-K) and immune-staining for CD3 (D) and IgG1 positive cells $(\mathbf{H})$. A representative inflammatory focus in one mouse of six to seven mice per treatment group is presented. Inflammatory foci are indicated inside dotted lines in a representative $4 \mathrm{~mm}^{2}$ histology section of the Harderian gland of one mouse from each treatment group (I-K). Scale bar, $100 \mu \mathrm{m}$. Quantification of inflammatory foci in the Harderian and salivary glands of wild type $(n=7), \operatorname{Rag} 2$ $\mathrm{KO}(n=6)$, and TCR $\beta$-TCR $\delta \mathrm{KO}(n=6)$ mice $(\mathbf{L})$. Data presented are individual values plotted with a bar indicating the group mean. Differences between the groups of measurements were analyzed by Kruskal-Wallis with post-test comparison. Focus scores of the Harderian glands in E. coli-treated group were significantly higher $(p<0.05)$ compared to all other measurement groups $(\mathbf{L})$.

\subsection{Identification of OmpA from E. coli as a Representative Immunogenic Protein in Mice}

We sought to identify the cellular component of E. coli that contributes to the generation of autoimmunity. Cell surface extracts of $E$. coli separated on 2-D gels showed numerous numbers of proteins at molecular weights between 25-100 kDa and pI 6-11 (Figure 3A). Western blotting of 2-D PAGE gel-transferred nitrocellulose membrane probed with sera of the experimental dacryoadenitis mice showed an immune-reactive protein migrating at $41 \mathrm{kDa} / \mathrm{pI} 6.24$ (Figure 3B), which was not detected with sera of mice inoculated with PBS alone (Figure 3C). Analysis of the $41 \mathrm{kDa} / \mathrm{pI} 6.24$ spot excised from the 2-D PAGE-gel of E. coli surface fraction by MALDI-TOF mass spectrometry was 
identified as OmpA (theoretical Mw/pI of 35,081.25/5.42), with MS-fit sequence coverage of 38\% (Figure 3D). To elucidate the immunogenicity of OmpA in vivo, sera of mice treated once a week during eight weeks with E. coli was validated by the production of antibodies against OmpA. Serum anti-OmpA antibody titer levels were elevated by systemic E. coli injection and were increased over time up to 10 months after completion of the final injection of E. coli (Figure 3E).

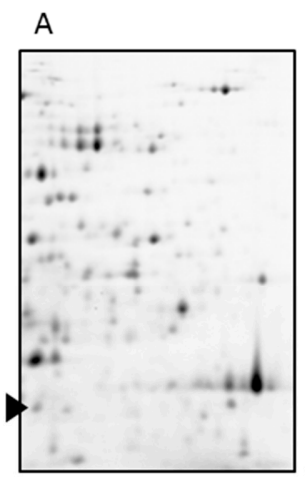

B

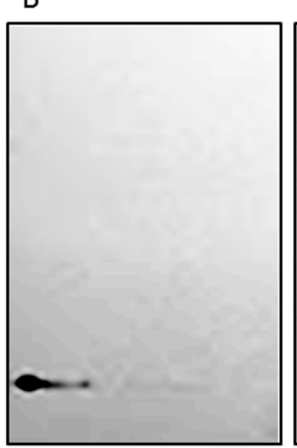

$E$

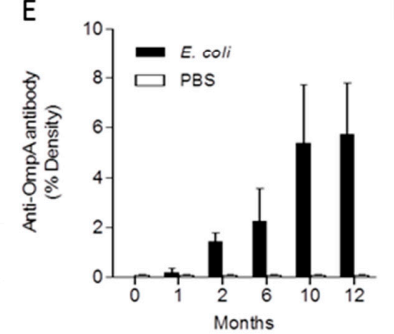

$\mathrm{C}$

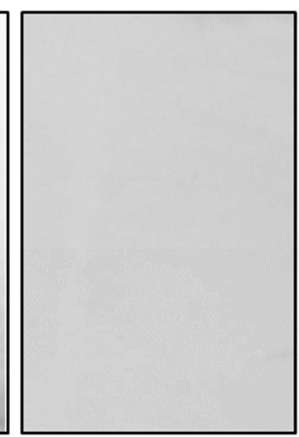

$\mathrm{F}$

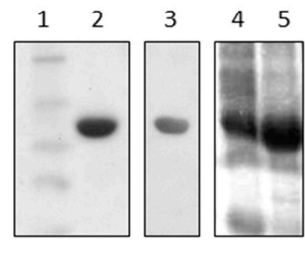

Figure 3. Immunogenic protein in E. coli-treated mouse model. Cell surface proteins of E. coli were separated on 2-D PAGE (A). Western blotting of 2-D gel-transferred nitrocellulose membrane was probed with serum of E. coli-treated mouse (B), or serum of mouse treated with PBS alone (C). Representative membranes of similar Western blotting results with sera of three sets of mice are shown. A spot of $41 \mathrm{kDa} / \mathrm{pI} 6.24$ in E. coli-surface extract reacting with sera from E. coli-treated mouse was excised from the 2-D gel (arrow head in A). OmpA was identified by MALDI-TOF/MS using peptide mass fingerprinting (Matrix Science, London, UK) and the non-redundant National Center for Biotechnology Information (NCBI) database (US National Library of Medicine, Bethesda, MD, USA) with a Mascot search engine (Matrix Science) through the BioTools 3.0 interface (Bruker Daltonics, Billerica, MA, USA). Matched peptides from the MS-fit data are shown in bold red (D). Anti-OmpA antibodies in sera of mice were compared between those of $E$. coli-treated mice $(n=5)$, and those of PBS-treated mice $(n=5)$ at indicated time after the final injection $(p=0.02$ at 1 month, $p<0.01$ at 2, 6, 10, and 12 months, Mann-Whitney $U$ test) (E). Recombinant OmpA was expressed and purified (F). Molecular weight markers indicate 58, 46, 30, 25, and $17 \mathrm{kDa}$, respectively (lane 1). $\mathrm{Ni}^{2+}$-affinity column-purified hexahistidine $(6 \times$ His)-tagged-OmpA (Lane2). Western blotting of whole cell lysate of BL21 (DE3) transformed with pQE2::ompA probed with anti-OmpA monoclonal antibody clone 49.4-15 [28] (lane 3). SDS-PAGE of whole cell lysate of BL21 (DE3) pQE2::ompA before (lane 4) and after isopropyl $\beta$-D-1-thiogalactopyranoside (IPTG) induction (lane 5).

\subsection{Analysis of the Amino Acid Sequences of OmpA from Phylum Proteobacteria}

Phylogenetic analysis of OmpA from phylum Proteobacteria showed that the bacteria from ten genera of the Enterobacteriaceae family (Escherichia, Salmonella, Citrobacter, Cronobacter, Enterobacter, Klebsiella, Pantoea, Serratia, Erwinia, and Yersinia) possessed OmpA with highly similar amino acid residues (Figure 4A,B). Residues corresponding to OmpA G80 to P305 of E. coli ATCC 25922 were aligned for analysis by using ClustalW, gap open penalty 1, gap extention penalty 0.05 . The similarity scores of OmpA amino acid sequences of Enterobacteriaceae compared to E. coli were $69-92 \%$, indicating that the amino acid residues were highly conserved among Enterobacteriaceae. 
Excluding the Enterobacteriaceae family, other orders of the class Gammaproteobacteria (genera Pasteurella, Gallibacteruim, Glaesserella, Bibersteina, Acinetobacter, Actinobacillus, Haemophillus, Vibrio, and Pseudomonas) were less similar to E. coli in the OmpA sequence (Figure 4A). Of the Proteobacteria phyla, classes Betaproteobacteria (genera Burkholderia and Bordetella, Figure 4A) and Alphaproteobacteria (genus Rickettsia) were also less similar to E. coli in the OmpA sequence.

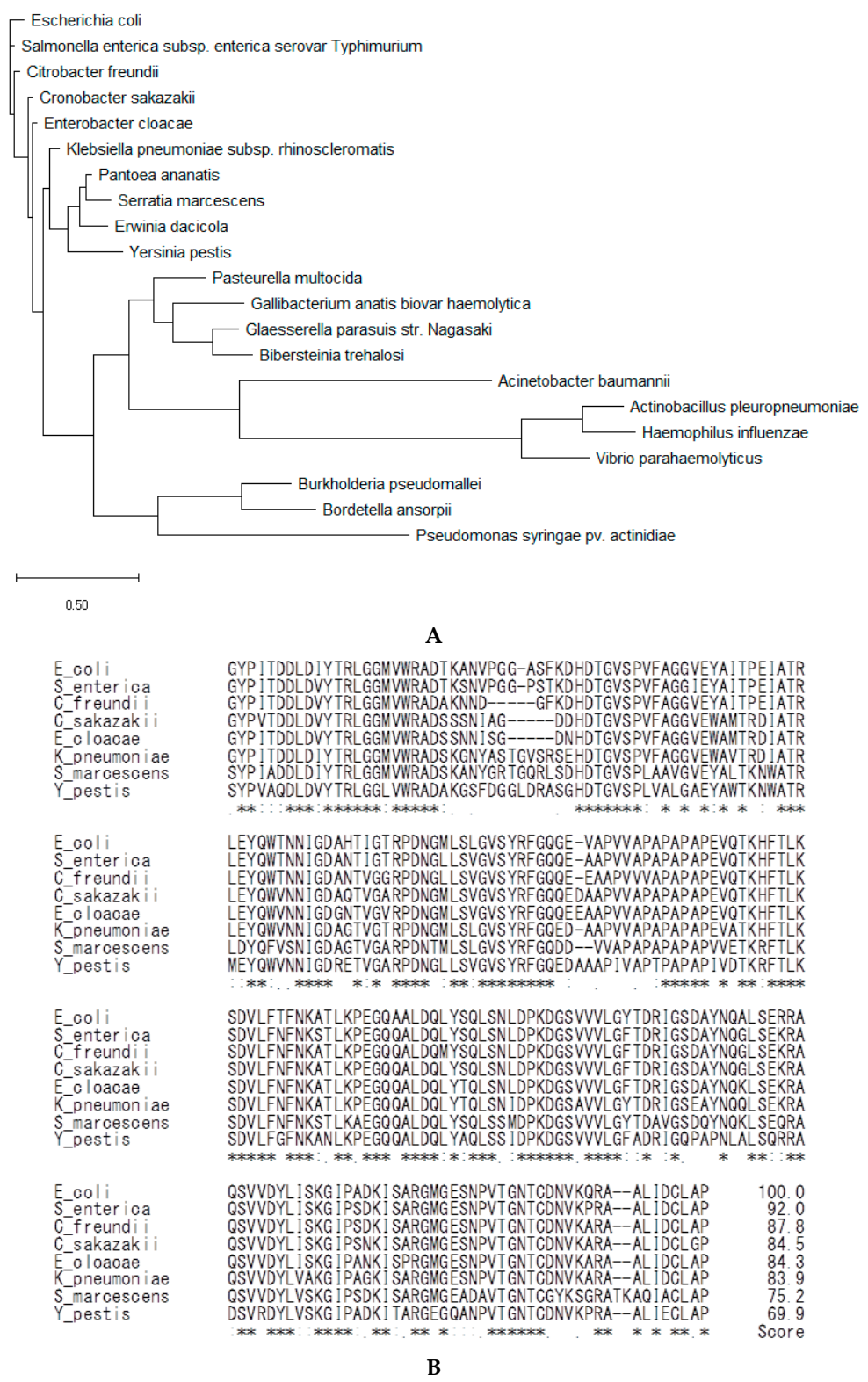

Figure 4. Phylogenetic analysis of the Proteobacteria pylum based on OmpA amino acid sequences by Maximum Likelihood method conducted on MEGA X software (Molecular Evolutionary Genetics Analysis, State College, PA, USA), as described in Reference [29]. The tree is drawn to scale, with branch lengths measured in the number of substitutions per site. Genera of Proteobacteria phylum included those of classes Gammaproteobacteria and Betaproteobacteria (A). Multiple sequence alignment of OmpA G80 to P305 of E. coli ATCC 25922 with amino acids of Gammaproteobacteria/Enterobacteriales by ClustalW (Available online: https:/ /www.genome.jp/tools-bin/clustalw). Conserved residues are highlighted with asterisks. Amino acids exhibiting strong and weak similarities according to point-accepted-mutation are indicated by colons and points, respectively. Scores (\%) of aligned similarities compared with those of E. coli ATCC 25922 are shown (B). 


\subsection{Induction of Extra-Intestinal Gland Inflammation by OmpA}

OmpA of E. coli was cloned and expressed as an N-terminal $6 \times$ His-tagged recombinant protein by IPTG induction (Figure 3F, lanes 4 and 5). Purification of $6 \times$ His-OmpA (Figure 3F, lane 2) using $\mathrm{Ni}^{2+}$-affinity column resulted in elution of a single band, which reacted to OmpA-specific monoclonal antibody [28] (Figure 3F, lane 3). To investigate on the effect of the immunogenic OmpA protein, recombinant OmpA was injected to mice intraperitoneally once a week for eight weeks. Inoculation of the full length OmpA resulted in inflammatory cell infiltration of the Harderian glands at fifteen weeks (Figure 5A,E) and at twenty-two weeks (Figure 5F,H), after the final injection. Inflammation of the Harderian glands was observed in all eight mice per group, whereas no inflammatory cells were detected in those after inoculation of PBS (Figure 5I). Infiltrating cells in the Harderian glands of the OmpA-treated mice were in part CD3- (Figure 5B,G), CD4- (Figure 5C), and CD8- (Figure 5D) positive cells detected by immunohistochemistry, which were not detected in those of the PBS-treated mice. OmpA induced inflammation in the salivary glands in three of the eight mice per group, but not in the pancreas (Figure 5I).
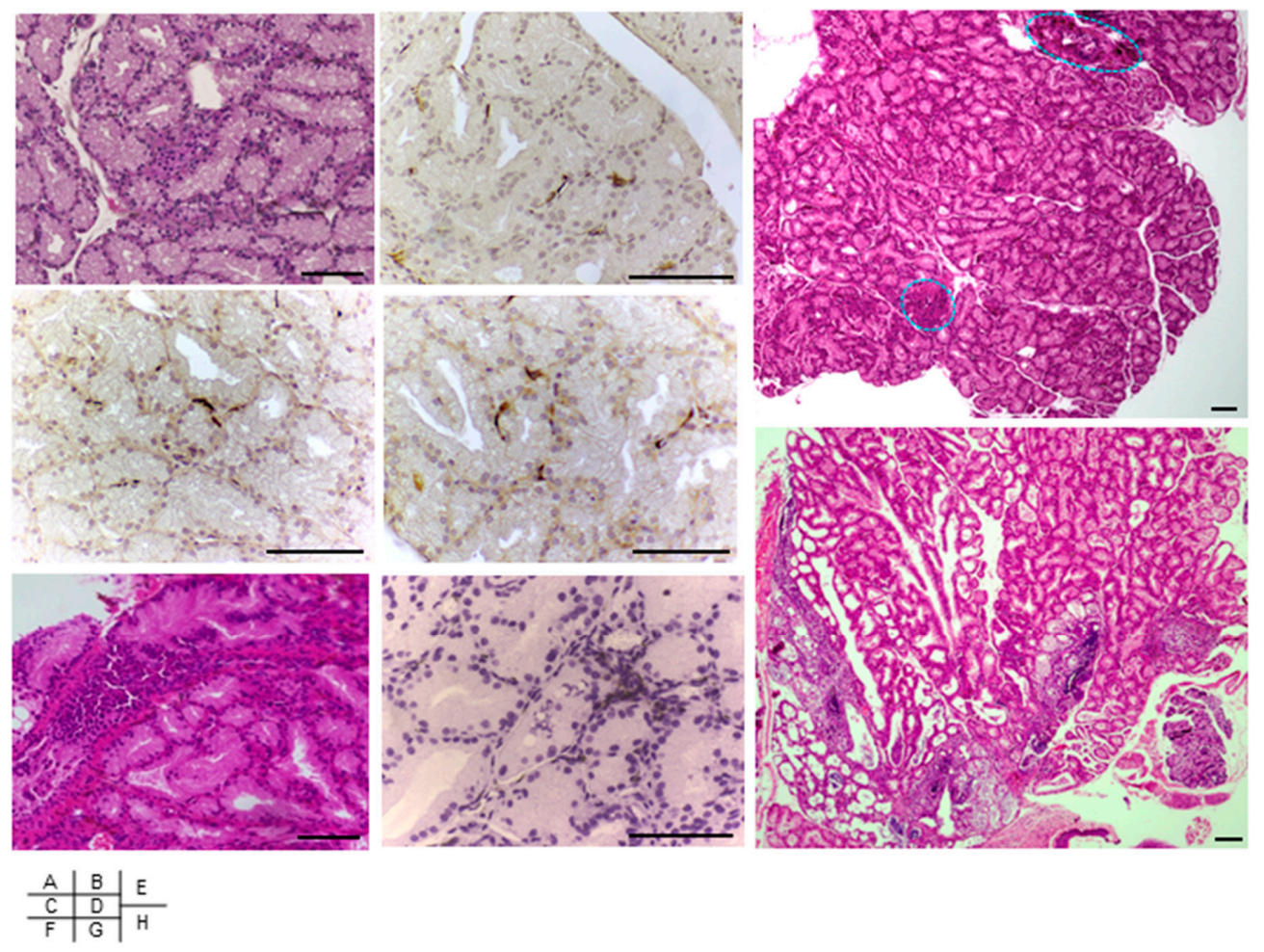

Figure 5. Cont. 


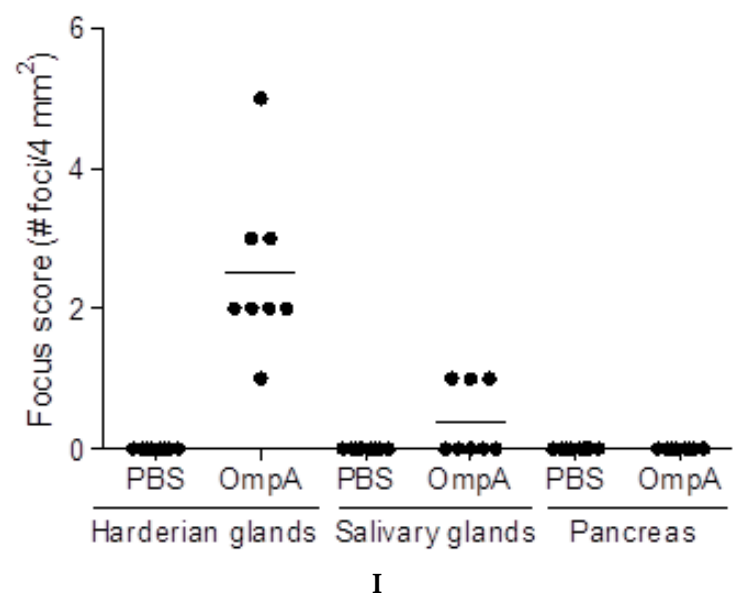

Figure 5. Histology of mice injected with OmpA. Harderian glands of C57BL/6 mice inoculated once a week during eight weeks with OmpA $(\mathbf{A}-\mathbf{H})$ were examined by HE-staining $(\mathbf{A}, \mathbf{E}, \mathbf{F}, \mathbf{H})$ and immune-staining for CD3 (B,G), CD4 (C), and CD8 (D), at fifteen weeks (A-E) or twenty-two weeks (F-H) after the final injection, in magnifications at $20 \times(\mathbf{A}-\mathbf{D}, \mathbf{F}, \mathbf{G})$ and $4 \times(\mathbf{E}, \mathbf{H})$. Dotted lines indicate inflammatory foci in a representative $4 \mathrm{~mm}^{2}$ of one mouse, fifteen weeks after the final inoculation of OmpA (E). Scale bar, $100 \mu \mathrm{m}$. Quantification of inflammatory foci in Harderian glands, salivary glands, and pancreas, fifteen weeks after the final inoculation of OmpA (I). Data presented are individual values $(n=8)$ plotted with a bar indicating the group mean. Differences between the groups of measurements were analyzed by Kruskal-Wallis with post-test comparison. Focus scores of the Harderian glands in OmpA-treated group were significantly higher $(p<0.05)$ compared to all other measurement groups $(\mathbf{I})$.

\subsection{Cytokine Production in Sera of Mice with Extra-Intestinal Inflammation Induced by OmpA}

Levels of cytokines in mice sera were measured, since systemic inflammatory responses may be able to trigger extra-intestinal gland inflammation. IFN- $\gamma$ and IL-17A inflammatory cytokine levels and IL-1 $\beta$ innate inflammatory cytokine level were up-regulated in the sera of OmpA- and E. coli-treated mice, compared to those of the PBS-inoculated control mice. However, E. coli or OmpA administration did not affect IL-10, IL-5, and TNF- $\alpha$ production in sera (Figure 6).
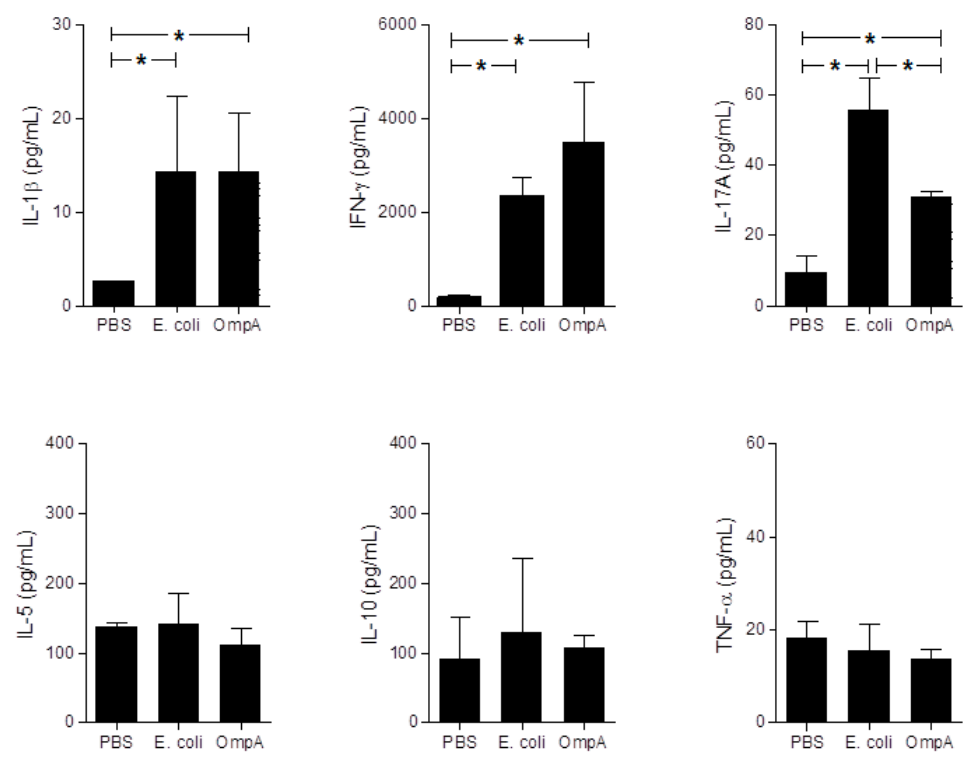

Figure 6. Cytokine production in mice injected with OmpA. Levels of IL-1 $\beta$, IL-5, IL-10, IL-17A, IFN- $\gamma$, and TNF- $\alpha$ in sera of PBS $(n=8)-$, E. coli $(n=8)-$, and OmpA $(n=8)$-treated mice were assessed using ELISA. Data presented as mean \pm SEM analyzed by Kruskal-Wallis with post-test comparison. * $p<0.05$. 


\subsection{Effect of Autoantibody Production by OmpA}

Anti-SSA/Ro and anti-SSB/La antibodies are autoantibodies elevated in sera of patients with systemic autoimmune diseases such as rheumatoid arthritis, lupus, and SS [30,31]. Thus, we examined whether OmpA-treated mice produced autoantibodies similar to those in autoimmune patients. Serum levels of anti-SSA/Ro antibodies and anti-SSB/La antibodies were elevated in OmpA- and E. coli-inoculated mice, compared to those inoculated with PBS (Figure 7). The data together with the histology of the inflammation in the extra-intestinal glands suggested that our model mouse had developed systemic autoimmune responses.
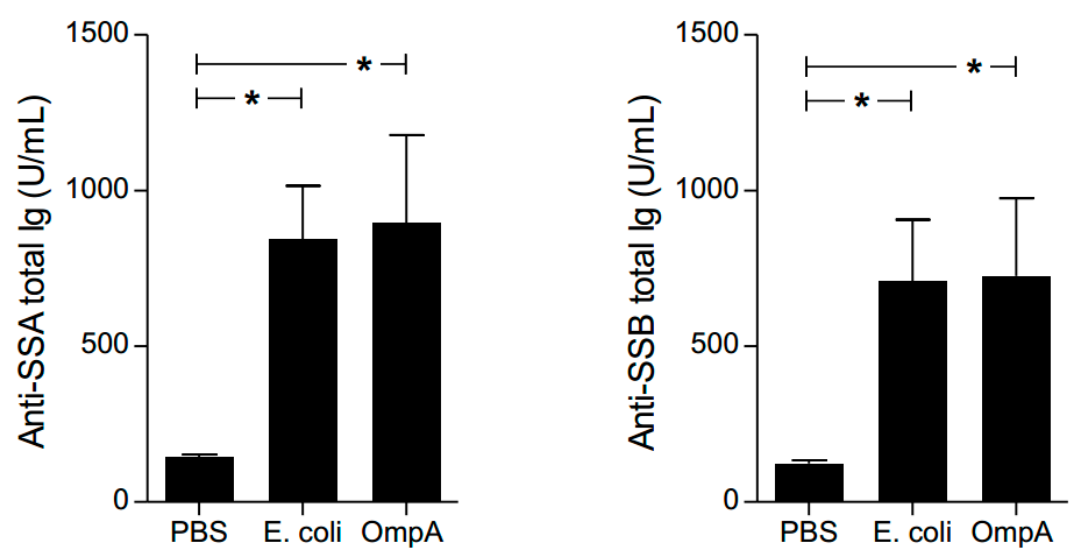

Figure 7. Autoantibody production by bacteria and bacteria-derived OmpA. Levels of anti- SSA/Ro and SSB/La antibodies in sera of PBS $(n=8)-$, E. coli $(n=8)-$, and OmpA $(n=8)$-treated mice were assessed using ELISA. Data presented are mean \pm SEM analyzed by Kruskal-Wallis with post-test comparison. ${ }^{*} p<0.05$.

\section{Discussion}

The human gut harbors a highly complex microbial community that allows the digestion of diet and has profound influence on the immune health, hence dysbiosis has been implicated in the immune tolerance modulation or the development of autoimmunity. We previously reported on the significant role of a commensal bacterial strain of E. coli in the systemic immune activation and the generation of exocrinopathy in mice [32]. In the mice of the present study, the Harderian and salivary glands showed infiltrates of inflammatory cells by E. coli-treatment. Dysbiosis of the gut commensal bacteria have been reported to be associated with autoimmune disease severity [16,33-35]. In the present study, we found that repeated inoculation of OmpA from commensal E. coli could induce autoantibody production accompanied by inflammation of the Harderian and salivary glands in mice. Anti-SSA/Ro and anti-SSB/La antibodies have been reported to be elevated in sera of patients with autoimmune diseases upon exposure to intracellular autoantigens, which are discharged into the microenvironment through secretion of autoantigen-containing exosomes or by cell death [31]. The development of the pathologic responses in mice by OmpA may be due to chronic systemic immune activation and autoimmunity.

Microbe-derived structures have been reported to possess the ability to induce autoimmune diseases in experimental animals [36]. Chronic stimuli of the immune system may be provided by extra-intestinal translocation or overgrown microorganisms of a dysbiotic gut. To address the role of microbe-derived molecules in the patho-etiology of autoimmunity, normal mice were stimulated repeatedly with a broad range of pathogen-associated molecular patterns (PAMPs) (PG, TLR-2 ligand; LTA, TLR-2 ligand; MDP, NOD-2 ligand; LPS, TLR-4 ligand). Stimulation with PGN, MDP, LTA, or LPS did not induce infiltration of inflammatory cells in the Harderian or salivary glands. It may be possible that the molecules did not possess the combined functionality of immunogenic antigens and bystander adjuvants [37], which are indispensable for autoimmunity [38]. In addition to the microbial 
molecules investigated in the present study, we previously studied the flagellar filament structural protein FliC, a TLR5-ligand, and an NLR apoptosis inhibitory protein (NAIP) activator, derived from commensal E. coli, which was repeatedly inoculated following the same regimen of injection as the present study $[17,39]$. In the reports, we had found that sialadenitis and pancreatitis could be induced by FliC in mice within the fifteen weeks of observation after the final inoculation $[17,39]$. The results of the present study indicated that OmpA was highly antigenic to induce humoral adaptive immune response to elicit antibodies and to encounter histological inflammation of the Harderian and the salivary glands, but not of the pancreas, indicating that different microbe-derived proteins had initiated inflammation in exocrine glands with tropism.

In our previous study, pancreas of mice after E. coli-derived FliC treatment showed infiltration of inflammatory cells, and the majority of the infiltrated cells were $\mathrm{CD}^{+} \mathrm{T}$ cells [39]. In the present study, inflammation of the Harderian glands was reproduced in immune-deficient Rag2 $\mathrm{KO}$ mice and in mature T cell-deficient TCR $\beta$-TCR $\delta$ KO mice by adoptive transfer of splenocytes or $\mathrm{CD}^{+} \mathrm{T}$ cells, respectively, from $E$. coli-treated mice. The results suggested that the exogenously administered E. coli-derived peptides possessed the ability to encounter cell-mediated immune response. Enterobacteriaceae, such as E. coli and Klebsiella pneumoniae, have the ability to use its cell surface OmpA to bind and to incorporate into dendritic cells (DCs) [40,41]. Salmonella OmpA induces expression of MHC class II and co-stimulatory molecules on DCs in mice [42] and differentiate naïve $\mathrm{CD} 4^{+} \mathrm{T}$ cell biased towards Th1 and Th17 [42-45]. In our mouse model, IL-1 $\beta$, IFN- $\gamma$, and IL-17A were inflammatory cytokines that were predominantly produced in sera, similar to the cytokine production by FliC [17]. In addition to cytokine production, OmpA of Klebsiella pneumoniae after endocytosis by DCs has been shown to gain access to the cytosolic MHC class I presentation pathway to elicit cytotoxic $\mathrm{T}$ cells (CTLs), in the absence of $\mathrm{CD} 4^{+} \mathrm{T}$ cell help or adjuvant. This property of OmpA has been explained by its ability to bind scavenger receptors, such as LOX-1 [21,46], and favor antigen targeting to and cross-priming by DCs [40], which may explain the positivity of CD8 ${ }^{+} \mathrm{T}$ cells in the Harderian glands in OmpA-treated mice in the present study.

Although exact mechanisms remain unknown, shared epitopes between proteins of the host and the microbiome have been proposed in the initiation of autoimmune diseases. In autoimmune pathology, sequence similarity of skin, oral, and gut commensal bacteria with autoantigens of SS and lupus [16], and cross-reaction of envelope proteins in spondyloarthritis patients have been reported [47], which may in part explain the link between dysbiosis and the pathology of autoimmunity [14]. The Enterobacteriaceae family possesses OmpA with high post-transcriptional sequence similarities, indicating that the conserved sequence could be shed from a broad spectrum of microbiota. It may thus be speculated that not only E. coli, as in the present study, but multiple microorganisms belonging to the Enterobactericacea family may potentially trigger initiation of autoimmunity. Validation of sequence differences of OmpA in patient isolates will allow further elucidation of the role of OmpA in the pathogenesis of autoimmunity.

In conclusion, we found a novel antigen of the commensal bacteria with a possible association to the pathogenesis in autoimmunity in mice. The highly immunogenic OmpA may be responsible for E. coli to induce innate and Th1/Th17-associated pro-inflammatory cytokines and CTLs, which may contribute to the acinar cell destruction of exocrine glands. Since we were not able to elucidate the interaction of OmpA with the exocrine glands, future analysis is needed to determine responsible OmpA residues for autoantibody production. Peptide sequence differences may explain the inflammatory involvement in the pancreas by FliC, but not by OmpA, despite similar cytokine production by the two Enterobactericeae derivatives. 


\section{Materials and Methods}

\subsection{Bacterial Strains, Culture Conditions and Bacteria-Derived Components}

A nonpathogenic human isolate E. coli strain ATCC $25922\left(b f p A^{-}, e a e A^{-}, s t^{-}, l t^{-}, s t x 1^{-}, s t x 2^{-}\right.$, $i a l^{-}, a g g R^{-}, d a a E^{-}$) was used for animal injection experiments [32]. Bacteria were cultured in Brain Heart Infusion broth (BD Pharmingen, Franklin Lakes, NJ, USA) aerobically for $18 \mathrm{~h}$ at $37^{\circ} \mathrm{C}$ with vigorous shaking. Bacteria were then harvested, washed twice with PBS (pH 7.4), resuspended in PBS, and heated at $80^{\circ} \mathrm{C}$ for $30 \mathrm{~min}$. E. coli DH5 $\alpha$ (TaKaRa Bio, Shiga, Japan) and BL21 (DE3) (New England Biolabs, Ipswich, MA, USA) were used to clone and to express recombinant proteins, respectively, and were cultured in Luria-Bertani (LB) medium (Invitrogen, Life Technologies, Carlsbad, CA, USA) incorporated with $50 \mu \mathrm{g} / \mathrm{mL}$ ampicillin (Sigma Chemicals, St. Louis, MO, USA). LPS from E. coli, PGN and LTA from Staphylococcus aureus, were purchased from Sigma Chemicals. MDP was purchased from Invitrogen.

\subsection{Mice}

C57BL / 6 wild type mice and TCR $\beta$-TCR $\delta$ knockout $(\mathrm{KO})$ mice on C57BL/ 6 background were purchased from Sankyo Labo Service Corporation (Tokyo, Japan) and The Jackson Laboratories (Bar Harbor, ME, USA), respectively. Rag2 KO mice on C57BL/ 6 background were kindly provided by Professor Ryo Abe (Tokyo University of Science, Tokyo, Japan). Six weeks old female mice were used for the experiments. All experiments were performed in the animal facility at the Department of Microbiology and Immunology, Tokyo Women's Medical University (TWMU), approved by the Ethics Review Committee for Animal Experiments, TWMU (project identification code AE18-061, approval date 30 March 2018).

\subsection{Treatment of Mice with Bacteria and Bacterial Components}

Mice were treated with or without bacteria or bacterial cell wall components. Heat-killed E. coli ( $2 \times 10^{7}$ colony forming units), $10 \mu \mathrm{g}$ of PGN, MDP, LTA, LPS or recombinant OmpA in $200 \mu \mathrm{L}$ PBS, respectively, were injected intraperitoneally once a week for a total of 8 weeks. Each treatment group consisted of seven to eight mice. Mice were sacrificed to obtain samples subsequent to euthanasia with carbon dioxide at the indicated time after the final injection.

\subsection{Isolation of Extra-Intestinal Gland Tissues}

Harderian glands and submandibular salivary glands were removed following euthanasia. Tissue was fixed in $10 \%$ buffered formalin.

\subsection{Sera Collection}

Mice were bled by cardiac puncture after euthanasia. Samples were placed at room temperature for $2 \mathrm{~h}$, centrifuged at $900 \times \mathrm{g}$ for $20 \mathrm{~min}$, and sera were collected and stored at $-20^{\circ} \mathrm{C}$ until use.

\subsection{Adoptive Transfer Experiments}

Single-cell suspensions from spleen of C57BL/ 6 wild type mice injected once a week during eight weeks with E. coli, OmpA, or PBS, were obtained at one week after the final inoculation. Bulk spleen cells, or splenic T cells separated using anti-mouse CD4 antibody by magnetic beads on AutoMACS (Miltenyi Boitec, Bergisch Gladbach, Germany) were transferred intravenously to Rag2 $\mathrm{KO}$ and TCR $\beta$-TCR $\delta \mathrm{KO}$ mice on C57BL/ 6 background, respectively. Each treatment group consisted of six mice. Mice were sacrificed one week after cell transfer to obtain tissue samples. 


\subsection{Histology}

Tissue preparation was described previously in Reference [31]. Briefly, four micrometer-thick sections of Harderian and salivary glands were stained with HE. For immunohistochemical assessment, sections were deparaffinized, rehydrated, and then heated in $10 \mathrm{mM}$ sodium citrate buffer $(\mathrm{pH}$ 6.0) for $20 \mathrm{~min}$ at $121^{\circ} \mathrm{C}$ for antigen retrieval. Subsequently, sections were incubated with $0.3 \% \mathrm{H}_{2} \mathrm{O}_{2}$ in methanol for inhibition of endogenous peroxidase for $30 \mathrm{~min}$ and incubated with primary antibodies diluted 1:30 in 1\% bovine serum albumin in PBS (BSA-PBS) for $60 \mathrm{~min}$ at room temperature. Primary biotinylated antibodies included hamster anti-CD3 $\varepsilon$ (clone 145-2C11; BD Pharmingen), rat anti-CD4 (clone RM4-5; BD Pharmingen), rat anti-CD8 $\alpha$ (clone 53-6.7, BD Pharmingen), which were detected by horse radish peroxidase (HRP)-conjugated streptavidin (Dako, Glostrop, Denmark), and rabbit anti-IgG1 (Novus Biologicals, Littleton, CO, USA), which was detected by EnVision FLEX (Dako). Immunoreactivity was visualized using 3,3'-diaminobenzidine substrate chromogen (Dako), counterstained with Mayer's hematoxylin (Muto Pure Chemicals, Tokyo, Japan). The slides were examined on Biorevo BZ9000 microscopy (Keyence, Osaka, Japan) and Vanox ADH (Olympus, Tokyo, Japan).

\subsection{Focus Scoring}

Inflammation in the exocrine gland was quantified using focus scores, as previously described in Reference [48]. Inflammation of at least 50 mononuclear cells was considered as a focus, and the numbers of inflammatory foci per $4 \mathrm{~mm}^{2}$ were determined as focus scores. Digital measurement of the surface area of the sections and the cell counts were performed on BZ-II Analyzer version 2.00 (Keyence). Inflamed specimen was determined by the presence of more than one focus. Total focus score was calculated for each individual mouse.

\subsection{Two Dimensional Polyacrylamide Gel Electrophoresis (2-D PAGE) of E. coli Cell Surface Proteins}

Water solubilization of E. coli ATCC 25922 surface proteins was performed as previously described in Reference [39]. No DNA was detectable in the spectrophotometric analysis at $260 \mathrm{~nm}$. Then, 2-D PAGE was performed with $200 \mathrm{mg}$ of the surface protein extract on Ettan IPGphor3 IEF using Immobiline DryStrip pH 6-11 (GE Healthcare, Little Chalfont, Buckinghamshire, UK), and 10\% acrylamide gels with molecular weight markers between 25-100 kDa (Nippon Gene, Tokyo, Japan). Spot detection and matching were performed using Multi Gauge Software on FLA5100 (Fuji Film, Tokyo, Japan).

\subsection{Western Blotting of Immunoreactive E. coli Surface Proteins}

Proteins resolved in 2-D PAGE were transferred to nitrocellulose membrane (Bio-Rad Laboratories, Hercules, CA, USA), which was blocked in TBS-TM buffer $(10 \mathrm{mM}$ Tris- $\mathrm{HCl} \mathrm{pH} 7.4,0.9 \% \mathrm{NaCl}$, $0.05 \%$ Tween $20,10 \%$ skimmed milk) and incubated with serum of a mouse two months after the eighth inoculation of E. coli, or serum of a mouse treated with PBS alone, diluted 1:2000 in TBS-TM. Immunoreactive spots were detected using an Immunostar enhanced chemiluminescence kit (Wako Pure Chemical Industries, Osaka, Japan).

\subsection{Identification of Proteins Using MALDI-TOF-MS}

MALDI-TOF mass spectrometry (AutoflexII; Bruker Daltonics) was used for protein identification, as previously described in Reference [39]. Briefly, spots from SYPRO-Ruby (Life Technologies) stained 2-D PAGE gel were excised on EXQuest (Bio-Rad), and digested with trypsin (Trypsin Gold, Mass Spectrometry Grade; Promega Corporation, Fitchburg, WI, USA). Mass spectra were calibrated using a peptide calibration standard mono (Bruker Daltonics) and ran in the positive ion reflector mode and in a mass-to-charge ratio $(\mathrm{m} / \mathrm{z})$ range of $600-4000 \mathrm{Da}$. Peptide mass fingerprint (Matrix Science) was 
conducted using the non-redundant NCBI database (US National Library of Medicine) with MASCOT search engine (Matrix Science), through BioTools 3.0 interface (Bruker Daltonics).

\subsection{Recombinant OmpA Protein Purification and Anti-OmpA Antibody Measurement}

DNA fragments of the ompA gene encoding for OmpA1-325, was amplified by polymerase chain reaction (PCR) using InFusion DNA polymerase (TaKaRa Bio) and genomic DNA of E. coli ATCC 25922 as template. PCR products were inserted into TAGZyme pQE2 (Qiagen, Hilden, Germany) at SphI and HindIII sites (New England Biolabs) in E. coli DH5 $\alpha$, which were selected with $50 \mu \mathrm{g} / \mathrm{mL}$ ampicillin in LB medium. After IPTG induction of E. coli BL21 transformed with constructed plasmids, cells were lysed in the presence of EDTA-free protease inhibitor cocktail (Sigma Chemicals). Then, $6 \times$ His-tagged recombinant OmpA was purified by $\mathrm{Ni}^{2+}$-affinity chromatography (GE Healthcare). Protein purity was assessed by SDS-PAGE stained with Coomassie brilliant blue and Western blotting probed with anti-OmpA monoclonal antibody 49.415 [30]. After treatment with Detoxin Gel Endotoxin Removing Columns (TaKaRa Bio), endotoxin levels in the recombinant protein solution used for experiments were $<0.005 \mathrm{EU} / \mathrm{ml}$ measured by using the Toxin Sensor Chromogenic Limulus Amebocyte Lysate Endotoxin Assay Kit (GenScript, Piscataway, NJ, USA). Protein concentration was quantified with the bicinchoninic acid (BCA) assay (BioRad). Anti-OmpA antibody levels in sera were measured by detection with HRP-conjugated goat anti-mouse antibodies (BioSource, Camarillo, CA, USA) against purified recombinant OmpA on nitrocellulose membrane strips, followed by determination of the intensities using the ImageJ program/gel analyzer option (US National Institute of Health, Bethesda, MD, USA), as previously described in Reference [32].

\subsection{Bioinformatic Analysis of the OmpA Protein}

OmpA amino acid sequences from representative environmental and pathogenic strains of the Proteobacteria phyla deposited to NCBI (US National Library of Medicine) were subjected to phylogenetic analysis by using the Maximum Likelihood method (MEGA X software, Molecular Evolutionary Genetics Analysis) [29]. Gammaproteobacteria/Enterobacteriales/Enterobactericeae genera Escherichia, Salmonella, Citrobacter, Cronobacter, Enterobacter, Klebsiella, Serratia, Pantoea, Erwinia, and Yesinia; Gammaproteobacteria/Pasturellales/Pasturellaceae genera Pasteurella, Gallibacterium, Glaesserella, Bibersteinia, Acinobacillus, and Haemophilus; Gammaproteobacteria/ Pseudomonadales genera Pseudomonas and Acinetobacter; Gammaproteobacteria/Vibrionales genus Vibrio; Betaproteobacteria/Burkholeriales genera Burkholeriales and Bordetella; Alphaproteobacteria/ Rickettsiales genera Anaplasma and Rickettsia were included in the phylogenic analysis. OmpA amino acid sequences of Gammaproteobacteria/Enterobacteriales/Enterobactericeae: Escherichia coli (ATCC 25922), Salmonella enterica subsp. enterica serovar Typhimurium (GenBank AIH09359.1), Citrobacter freundii (GenBank AWW73248.1), Cronobacter sakazakii (GenBank AAY18798.1), Enterobacter cloacae (GenBankAAW 73250.1), Klebsiella pneumoniae (GenBank CCI75899.1), Serratia marcescens (GenBank ALE95511.1), and Yesinia pestis (GenBank AAM86287.1) were subjected to multiple sequence alignment (ClustalW, available online: https://www.genome.jp/tools-bin/clustalw).

\subsection{Enzyme-Linked Immunosorbent Assay (ELISA)}

Serum levels of anti-SSA/Ro and anti-SSB/La antibodies (Alpha Diagnostics International, San Antonio, TX, USA) were determined using ELISA kits according to the manufacturer's protocol. Serum inflammatory cytokines in mice sera were measured by sandwich-ELISA using capture antibodies against IL-1 $\beta$ (clone B122; eBioscience, Affymetrix Japan, Tokyo, Japan), IL-5 (clone TRFK5; eBioscience), IL-10 (clone JESS-16E3; eBioscience), IL-17A (clone 17CK15A5; eBioscience), IFN- $\gamma$ (clone XMG1.2; eBioscience), TNF- $\alpha$ (clone TN3-19.12; BD Pharmingen), and biotinylated-detection antibodies against IL-1 $\beta$ (clone 13-7112-85; eBioscience), IL-5 (clone TRFK4; eBioscience), IL-10 (clone JESS-2A5; eBioscience), IL-17A (clone 17B7; eBoiscience), IFN- $\gamma$ (clone R4-6A2; eBioscience), TNF- $\alpha$ (clone MP6-XT22; BD Pharmingen). All antibodies were diluted 1:1000 in PBS containing 
$10 \%$ fetal calf serum (Gibco, Thermo Fisher Scientific, Tokyo, Japan). Biotinated antibodies were detected by HRP-conjugated avidin (Vector laboratories, Burlingame, CA, USA) and visualized by 3,3',5,5'-tetramethylbenzidine (Dako), where the reaction was stopped with $2 \mathrm{M} \mathrm{H}_{2} \mathrm{O}_{2}$. Microtitier plate reader (Vmax, Molecular Devices, Tokyo, Japan) at $450 \mathrm{~nm}$ was used to measure the optical densities.

\subsection{Statistical Analysis}

Multiple comparisons of the data were performed using Kruskal-Wallis with a post-test comparing each group to all other groups on GraphPad Prism version 5 for Windows (GraphPad Software, San Diego, CA, USA). $p$-values $<0.05$ were considered as statistically significant.

Author Contributions: Conceptualization, N.Y. and T.H.; Data curation, N.Y., Y.A., H.U., and H.K.; Formal analysis, N.Y. and T.H.; Methodology, N.Y., H.U., H.K., and T.H.; Project administration, J.Y.; Supervision, J.Y.; Validation, N.Y. and H.U.; Visualization, Y.A. and H.U.; Writing—original draft, N.Y.; Writing—review \& editing, J.Y.

Funding: This research was funded by Scholarship Fund for Basic Researcher of Medical Science Keiko Watanabe Award, Shiseikai (\#1, N.Y.), Itoe Okamoto Scientific Award, Shiseikai (\#28, N.Y.), Takako Satake Scientific Award, TWMU (\#19, N.Y.).

Acknowledgments: Some data presented herein were obtained at the MALDI TOF/MS Facility, at Medical Research Institute (MRI), and the Imaging Facility at TWMU Institute for Integrated Medical Sciences (TIIMS), which are core research facilities of TWMU. The authors gratefully acknowledge Masamichi Yoshikawa for his skillful animal care. This paper is dedicated to the pioneer work of Ikuko Haruta.

Conflicts of Interest: The authors declare no conflict of interest.

\section{References}

1. Costello, E.K.; Lauber, C.L.; Hamady, M.; Fierer, N.; Gordon, J.I.; Knight, R. Bacterial community variation in human body habitats across space and time. Science 2009, 326, 1694-1697. [CrossRef] [PubMed]

2. Yatsunenko, T.; Rey, F.E.; Manary, M.J.; Trehan, I.; Dominguez-Bello, M.G.; Contreras, M.; Magris, M.; Hidalgo, G.; Baldassano, R.N.; Anokhin, A.P.; et al. Human gut microbiome viewed across age and geography. Nature 2012, 486, 222-227. [CrossRef] [PubMed]

3. Duriez, P.; Clermont, O.; Bonacorsi, S.; Bingen, E.; Chaventre, A.; Elion, J.; Picard, B.; Denamur, E. Commensal Escherichia coli isolates are phylogenetically distributed among geographically distinct human populations. Microbiology 2001, 147, 1671-1676. [CrossRef] [PubMed]

4. Tomas, J.; Reygner, J.; Mayeur, C.; Ducroc, R.; Bouet, S.; Bridonneau, C.; Cavin, J.B.; Thomas, M.; Langella, P.; Cherbuy, C. Early colonizing Escherichia coli elicits remodeling of rat colonic epithelium shifting toward a new homeostatic state. ISME J. 2015, 9, 46-58. [CrossRef] [PubMed]

5. Palmer, C.; Bik, E.M.; DiGiulio, D.B.; Relman, D.A.; Brown, P.O. Development of the human infant intestinal microbiota. PLoS Biol. 2007, 5, e177. [CrossRef] [PubMed]

6. Secher, T.; Brehin, C.; Oswald, E. Early settlers: Which E. coli strains do you not want at birth? Am. J. Physiol. Gastrointest. Liver Physiol. 2016, 311, G123-G129. [CrossRef] [PubMed]

7. Lundell, A.C.; Bjornsson, V.; Ljung, A.; Ceder, M.; Johansen, S.; Lindhagen, G.; Tornhage, C.J.; Adlerberth, I.; Wold, A.E.; Rudin, A. Infant B cell memory differentiation and early gut bacterial colonization. J. Immunol. 2012, 188, 4315-4322. [CrossRef] [PubMed]

8. $\quad$ Eckburg, P.B.; Bik, E.M.; Bernstein, C.N.; Purdom, E.; Dethlefsen, L.; Sargent, M.; Gill, S.R.; Nelson, K.E.; Relman, D.A. Diversity of the human intestinal microbial flora. Science 2005, 308, 1635-1638. [CrossRef] [PubMed]

9. Conway, T.; Cohen, P.S. Commensal and pathogenic Escherichia coli metabolism in the gut. Microbiol. Spectr. 2015, 3. [CrossRef] [PubMed]

10. Spees, A.M.; Wangdi, T.; Lopez, C.A.; Kingsbury, D.D.; Xavier, M.N.; Winter, S.E.; Tsolis, R.M.; Baumler, A.J. Streptomycin-induced inflammation enhances Escherichia coli gut colonization through nitrate respiration. mBio 2013, 4, e00430-13. [CrossRef] [PubMed]

11. Martinez-Medina, M.; Denizot, J.; Dreux, N.; Robin, F.; Billard, E.; Bonnet, R.; Darfeuille-Michaud, A.; Barnich, N. Western diet induces dysbiosis with increased E coli in CEABAC10 mice, alters host barrier function favouring AIEC colonisation. Gut 2014, 63, 116-124. [CrossRef] [PubMed] 
12. Kau, A.L.; Ahern, P.P.; Griffin, N.W.; Goodman, A.L.; Gordon, J.I. Human nutrition, the gut microbiome and the immune system. Nature 2011, 474, 327-336. [CrossRef] [PubMed]

13. Mu, C.; Yang, Y.; Luo, Z.; Zhu, W. Temporal microbiota changes of high-protein diet intake in a rat model. Anaerobe 2017, 47, 218-225. [CrossRef] [PubMed]

14. Zhao, Q.; Elson, C.O. Adaptive immune education by gut microbiota antigens. Immunology 2018, 154, 28-37. [CrossRef] [PubMed]

15. Lindskog Jonsson, A.; Caesar, R.; Akrami, R.; Reinhardt, C.; Fåk Hållenius, F.; Borén, J.; Bäckhed, F. Impact of gut microbiota and diet on the development of atherosclerosis in Apoe ${ }^{(-/-)}$Mice. Arterioscler. Thromb. Vasc. Biol. 2018, 38. [CrossRef] [PubMed]

16. Szymula, A.; Rosenthal, J.; Szczerba, B.M.; Bagavant, H.; Fu, S.M.; Deshmukh, U.S. T cell epitope mimicry between Sjögren's syndrome Antigen A (SSA)/Ro60 and oral, gut, skin and vaginal bacteria. Clin. Immunol. 2014, 152, 1-9. [CrossRef] [PubMed]

17. Higuchi, T.; Haruta, I.; Shibata, N.; Yanagisawa, N.; Yagi, J. Flagellar filament structural protein induces Sjögren's syndrome-like sialadenitis in mice. Oral Dis. 2017, 23, 636-643. [CrossRef] [PubMed]

18. Aoki, S.; Yoshikawa, K.; Yokoyama, T.; Nonogaki, T.; Iwasaki, S.; Mitsui, T.; Niwa, S. Role of enteric bacteria in the pathogenesis of rheumatoid arthritis: Evidence for antibodies to enterobacterial common antigens in rheumatoid sera and synovial fluids. Ann. Rheum. Dis. 1996, 55, 363-369. [CrossRef] [PubMed]

19. Marcoux, J.; Politis, A.; Rinehart, D.; Marshall, D.P.; Wallace, M.I.; Tamm, L.K.; Robinson, C.V. Mass spectrometry defines the $\mathrm{C}$-terminal dimerization domain and enables modeling of the structure of full-length OmpA. Structure 2014, 22, 781-790. [CrossRef] [PubMed]

20. Weiser, J.N.; Gotschlich, E.C. Outer membrane protein A (OmpA) contributes to serum resistance and pathogenicity of Escherichia coli K-1. Infect. Immun. 1991, 59, 2252-2258. [PubMed]

21. Smith, S.G.; Mahon, V.; Lambert, M.A.; Fagan, R.P. A molecular Swiss army knife: OmpA structure, function and expression. FEMS Microbiol. Lett. 2007, 273, 1-11. [CrossRef] [PubMed]

22. Arora, A.; Rinehart, D.; Szabo, G.; Tamm, L.K. Refolded outer membrane protein A of Escherichia coli forms ion channels with two conductance states in planar lipid bilayers. J. Biol. Chem. 2000, 275, 1594-1600. [CrossRef] [PubMed]

23. Prasadarao, N.V.; Blom, A.M.; Villoutreix, B.O.; Linsangan, L.C. A novel interaction of outer membrane protein A with C4b binding protein mediates serum resistance of Escherichia coli K1. J. Immunol. 2002, 169, 6352-6360. [CrossRef] [PubMed]

24. Fu, H.; Belaaouaj, A.A.; Dahlgren, C.; Bylund, J. Outer membrane protein A deficient Escherichia coli activates neutrophils to produce superoxide and shows increased susceptibility to antibacterial peptides. Microbes Infect. 2003, 5, 781-788. [CrossRef]

25. Vila-Farres, X.; Parra-Millan, R.; Sanchez-Encinales, V.; Varese, M.; Ayerbe-Algaba, R.; Bayo, N.; Guardiola, S.; Pachon-Ibanez, M.E.; Kotev, M.; Garcia, J.; et al. Combating virulence of Gram-negative bacilli by OmpA inhibition. Sci. Rep. 2017, 7, 14683. [CrossRef] [PubMed]

26. Payne, A.P. The harderian gland: A tercentennial review. J. Anat. 1994, 185, 1-49. [PubMed]

27. Terao, M.; Kurosaki, M.; Barzago, M.M.; Fratelli, M.; Bagnati, R.; Bastone, A.; Giudice, C.; Scanziani, E.; Mancuso, A.; Tiveron, C.; et al. Role of the molybdoflavoenzyme aldehyde oxidase homolog 2 in the biosynthesis of retinoic acid: Generation and characterization of a knockout mouse. Mol. Cell. Biol. 2009, 29, 357-377. [CrossRef] [PubMed]

28. Abe, Y.; Haruta, I.; Yanagisawa, N.; Yagi, J. Mouse monoclonal antibody specific for outer membrane protein A of Escherichia coli. Monoclon. Antib. Immunodiagn. Immunother. 2013, 32, 32-35. [CrossRef] [PubMed]

29. Tamura, K.; Battistuzzi, F.U.; Billing-Ross, P.; Murillo, O.; Filipski, A.; Kumar, S. Estimating divergence times in large molecular phylogenies. Proc. Natl. Acad. Sci. USA 2012, 109, 19333-19338. [CrossRef] [PubMed]

30. Oke, V.; Wahren-Herlenius, M. The immunobiology of Ro52 (TRIM21) in autoimmunity: A critical review. J. Autoimmun. 2012, 39, 77-82. [CrossRef] [PubMed]

31. Kyriakidis, N.C.; Kapsogeorgou, E.K.; Tzioufas, A.G. A comprehensive review of autoantibodies in primary Sjögren's syndrome: Clinical phenotypes and regulatory mechanisms. J. Autoimmun. 2014, 51, 67-74. [CrossRef] [PubMed] 
32. Haruta, I.; Yanagisawa, N.; Kawamura, S.; Furukawa, T.; Shimizu, K.; Kato, H.; Kobayashi, M.; Shiratori, K.; Yagi, J. A mouse model of autoimmune pancreatitis with salivary gland involvement triggered by innate immunity via persistent exposure to avirulent bacteria. Lab. Investig. 2010, 90, 1757-1769. [CrossRef] [PubMed]

33. De Paiva, C.S.; Jones, D.B.; Stern, M.E.; Bian, F.; Moore, Q.L.; Corbiere, S.; Streckfus, C.F.; Hutchinson, D.S.; Ajami, N.J.; Petrosino, J.F.; et al. Altered mucosal microbiome diversity and disease severity in Sjögren syndrome. Sci. Rep. 2016, 6, 23561. [CrossRef] [PubMed]

34. Tsigalou, C.; Stavropoulou, E.; Bezirtzoglou, E. Current insights in microbiome shifts in Sjögren's syndrome and possible therapeutic interventions. Front. Immunol. 2018, 9, 1106. [CrossRef] [PubMed]

35. Greiling, T.M.; Dehner, C.; Chen, X.; Hughes, K.; Iniguez, A.J.; Boccitto, M.; Ruiz, D.Z.; Renfroe, S.C.; Vieira, S.M.; Ruff, W.E.; et al. Commensal orthologs of the human autoantigen Ro60 as triggers of autoimmunity in lupus. Sci. Transl. Med. 2018, 10, eaan2306. [CrossRef] [PubMed]

36. Shimizu, S.; Kurashige, Y.; Nishimura, M.; Yamazaki, M.; Sato, J.; Saitoh, M.; Selimovic, D.; Abiko, Y. Involvement of toll-like receptors in autoimmune sialoadenitis of the non-obese diabetic mouse. J. Oral Pathol. Med. 2012, 41, 517-523. [CrossRef] [PubMed]

37. Van Aalst, S.; Ludwig, I.S.; van der Zee, R.; van Eden, W.; Broere, F. Bystander activation of irrelevant CD4 ${ }^{+}$ T cells following antigen-specific vaccination occurs in the presence and absence of adjuvant. PLoS ONE 2017, 12, e0177365. [CrossRef] [PubMed]

38. Kobayashi, M.; Yasui, N.; Ishimaru, N.; Arakaki, R.; Hayashi, Y. Development of autoimmune arthritis with aging via bystander T cell activation in the mouse model of Sjögren's syndrome. Arthritis Rheum. 2004, 50, 3974-3984. [CrossRef] [PubMed]

39. Yanagisawa, N.; Haruta, I.; Shimizu, K.; Furukawa, T.; Higuchi, T.; Shibata, N.; Shiratori, K.; Yagi, J. Identification of commensal flora-associated antigen as a pathogenetic factor of autoimmune pancreatitis. Pancreatology 2014, 14, 100-106. [CrossRef] [PubMed]

40. Jeannin, P.; Renno, T.; Goetsch, L.; Miconnet, I.; Aubry, J.P.; Delneste, Y.; Herbault, N.; Baussant, T.; Magistrelli, G.; Soulas, C.; et al. OmpA targets dendritic cells, induces their maturation and delivers antigen into the MHC class I presentation pathway. Nat. Immunol. 2000, 1, 502-509. [CrossRef] [PubMed]

41. Torres, A.G.; Li, Y.; Tutt, C.B.; Xin, L.; Eaves-Pyles, T.; Soong, L. Outer membrane protein A of Escherichia coli O157:H7 stimulates dendritic cell activation. Infect. Immun. 2006, 74, 2676-2685. [CrossRef] [PubMed]

42. Lee, J.S.; Jung, I.D.; Lee, C.M.; Park, J.W.; Chun, S.H.; Jeong, S.K.; Ha, T.K.; Shin, Y.K.; Kim, D.J.; Park, Y.M. Outer membrane protein a of Salmonella enterica serovar Typhimurium activates dendritic cells and enhances Th1 polarization. BMC Microbiol. 2010, 10, 263. [CrossRef] [PubMed]

43. Gu, H.; Liao, Y.; Zhang, J.; Wang, Y.; Liu, Z.; Cheng, P.; Wang, X.; Zou, Q.; Gu, J. Rational design and evaluation of an artificial Escherichia coli $\mathrm{K} 1$ protein vaccine candidate based on the structure of OmpA. Front. Cell. Infect. Microbiol. 2018, 8, 172. [CrossRef] [PubMed]

44. Rainard, P.; Reperant-Ferter, M.; Gitton, C.; Gilbert, F.B.; Germon, P. Cellular and humoral immune response to recombinant Escherichia coli OmpA in cows. PLoS ONE 2017, 12, e0187369. [CrossRef] [PubMed]

45. Pore, D.; Mahata, N.; Chakrabarti, M.K. Outer membrane protein A (OmpA) of Shigella flexneri 2a links innate and adaptive immunity in a TLR2-dependent manner and involvement of IL-12 and nitric oxide. J. Biol. Chem. 2012, 287, 12589-12601. [CrossRef] [PubMed]

46. Jeannin, P.; Bottazzi, B.; Sironi, M.; Doni, A.; Rusnati, M.; Presta, M.; Maina, V.; Magistrelli, G.; Haeuw, J.F.; Hoeffel, G.; et al. Complexity and complementarity of outer membrane protein A recognition by cellular and humoral innate immunity receptors. Immunity 2005, 22, 551-560. [CrossRef] [PubMed]

47. Williams, K.M.; Raybourne, R.B. Demonstration of cross-reactivity between bacterial antigens and class I human leukocyte antigens by using monoclonal antibodies to Shigella flexneri. Infect. Immun. 1990, 58, 1774-1781. [PubMed]

48. Barr, J.Y.; Wang, X.; Meyerholz, D.K.; Lieberman, S.M. CD8 T cells contribute to lacrimal gland pathology in the nonobese diabetic mouse model of Sjögren syndrome. Immunol. Cell Biol. 2017, 95, 684-694. [CrossRef] [PubMed]

(C) 2018 by the authors. Licensee MDPI, Basel, Switzerland. This article is an open access article distributed under the terms and conditions of the Creative Commons Attribution (CC BY) license (http://creativecommons.org/licenses/by/4.0/). 